\title{
NOTES ON ETHNICAL COMPONENTS IN FORMING ARCHEOLOGICAL PICTURE OF SOUTWESTERN SERBIA AND NORTHERN MONTENEGRO IN PROTOHISTORY AND EARLY ROMAN PERIOD
}

The paper is devoted to recognition of ethnical components and their importance in creation of archaeological picture of South-Western Serbia and Northern Montenegro in proto-history and Early Roman period. The chosen region was an integral part of the Illyrian world, but on the threshold of the Thracian at the end of later prehistory. As for the subsequent period of Roman domination, one of the most important tasks for the future exploration is at least partial enlightening the structure of the population the Romans found in this area at the turn of the Christ Era. Either the new era or the Christian era.

Keywords: Iron Age, Roman period, Montenegro, Serbia, necropolises, Municipium S., Illyrians, Thracians.

If ethnical identity in the present is not easy to catch, then it should be expected that finding material record of it in the past is a tantalizing task. Ethnicity is widely seen as an intangible concept, multi-faceted and not firmly defined. It is expressed most often in the way individuals feel themselves connected - or the way others see them to be connected - to different social groups or to a specific social milieu. Such feelings and beliefs can reach almost mythological dimensions. Although ethnical components in identity may change along with social and historical circumstances, people (individuals and social groups) regularly use ethnicity to support and / or legitimize political entities or economic systems, in the past as well as in modern times (cf. Knapp 2014 with further references).

Already the first glance at most general maps with emphasized Thracian ethnic and cultural space reveals specific position of the focal zone of the present study (cf. Fol, Popov, Yordanov 2014, p. 10). During the I millennium BC and at the turn of the new era Southwest Serbia and Northern
Montenegro (fig. 1) were an integral part of the Illyrian world, but on the threshold of the Thracian. The wider area shared between the modern states of Serbia and Montenegro bears traces of human presence, which go back to the Palaeolithic. In spite of the fact that in the $1960^{\mathrm{s}}, 1970^{\mathrm{s}}$ and $1980^{\mathrm{s}}$ and even later an intense archaeological research of the area was performed, resulting in discovery of a number of sites from the late prehistory and Roman period (Летица 1982; Јевтић 1996; Срејовић 2009; Цермановић-Кузмановић 2009), the state of exploration is still not satisfactory. One of the reasons for that lies in the environmental diversity. On the one hand the valleys of important rivers provided good connectivity. For example, if it is concerned that the Novi Pazar area is rich in smaller river flows belonging to the Raška and Ibar watershed, it is obvious how easily the influence from the south could reach inhabitants of these valleys. On the other hand the highlands today shared by Serbia and Montenegro and the wide Pešter plateau offer completely different life conditions. The Pešter plateau is sharply divided from the surrounding zones by both its height and its geomorphological characteristics. It is an area without forest, with average height $1100-1250 \mathrm{~m}$ above sea level, having characteristics of the karst and with very little water. It makes the shortest connection between the Raška and Lim valleys, and in broad sense between the Morava valley and the river Drina, i. e. between the eastern and the western parts of the Central Balkans. There is shortage of fertile soil, and the climate is not convenient for planting every sort of cereals and fruits. Fortunately, pasture is very spacious and rich in grass for grazing. Inside the Pešter plateau, the best life conditions can be found at Peštersko polje and Koštam polje — two troughs surrounded 


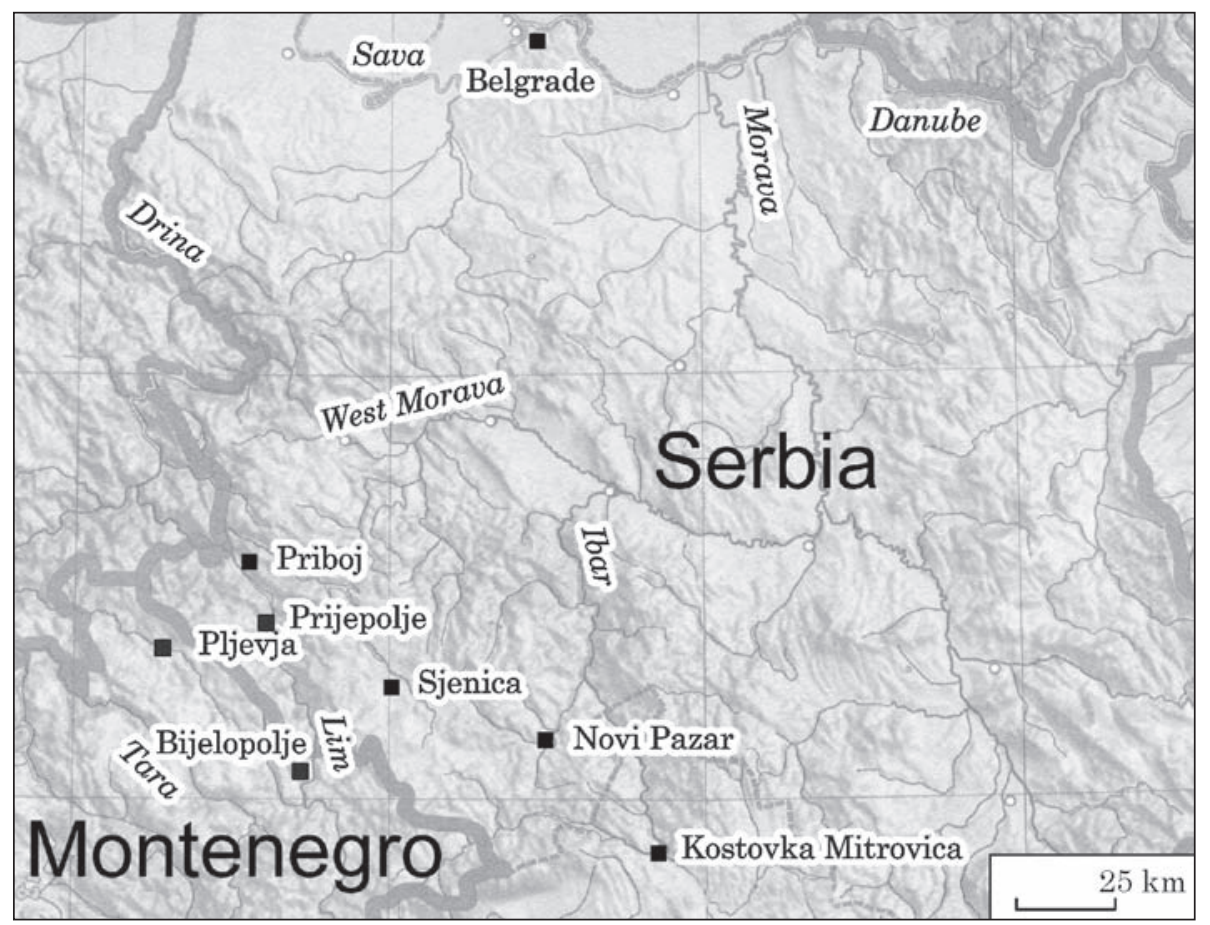

Fig. 1. Map of Bijelo Polje, Kosovska Mitrovica

by hills and relatively rich in water - which are inhabited with high density even today, as it was the case in the past.

Archaeological picture of the studied area is dominated by a significant number of tumular necropolises. The greatest number of tumular burials belongs to the final horizon of the First Iron Age / Hallstatt period. It is under no doubt that in the Late Hallstatt the area was incorporated in the cultural complex Glasinac-Mati. In spite of the fact that ethnic attribution of the complex was Illyrian in wider sense, some of the graves have specific material which can be connected with the north-Thracian cultural circle.

Thanks to the priority the Glasinac plateau got with the early start of excavations of the tumuli and hillforts, already in the $2^{\text {nd }}$ half of the $19^{\text {th }} \mathrm{c}$., the complex of archaeological sites from the territory of the Autariatae was attributed to the bearers of the Glasinac culture. On the other hand, even a glimpse into the geographic map provides enough information to claim that the area of SW Serbia and N Montenegro is in the heart of the Glasinac cultural complex or the territory of the Autariate. Consequently, archaeological sites from the region chronologically attributed to the Hallstatt period are memorabilia of the Autariatae (Benac 1987; Čović 1987; Лазић, Церовић 2008). Two areas of the region, the Novi Pazar area and the Pljevlja area, were chosen for the study due to their specific development inside the vast cultural complex. Each one of them revealed its own cultural development and final destiny.

Material culture of the Autariatae from Northern Montenegro is well known due to the archaeological excavations of tumuli. The region of the city of Pljevlja is of particular importance, since tumular necropolises were explored in Gotovuša, Ljutići near Mataruge, Lever Tara, Borovica and Otilovići (fig. 2). In most of the mounds, built of earth and stone, with outstanding complexity of funerary practices and several burial horizons, there were graves of inhumed deceased in supine position, with jewellery and elements of attire (most of them made of bronze, such as massive cast bracelets, decorated circular plates, arch fibulae and decorative pins), weapons and pottery. Ceramic repertoire is reduced to greyish beakers with one or two handles and incised geometric ornaments. In spite of the fact that in the Pljevlja area more than ten mounds with significant number of graves from the Hallstatt period have been explored, the archaeological material from the graves indicated mid- $5^{\text {th }} \mathrm{c}$. BC as the latest date. In contrast to it, in the Glasinac area and the Drina valley there were graves from later periods, which testified about prolonged and continual existence of the Autariatae, unlike in the region of Pljevlja (Лазић, Церовић 2008).

The greatest number of tumular burials in the Novi Pazar region belongs to the final horizon of the Halstatt period. Apart from the Novi Pazar princely grave, the remains of graves belonging to this horizon were found at more than ten sites (villages Crnoča, Glogovik, Delimeđe, Gračane, Melaje, Raspoganče, Doljani, and Novopazarska Banja), most of them being found under tumuli at the Pešter plateau. The picture of funerary practice during the Hallstatt period in the Novi Pazar area reveals neither chronological nor ethnical unity. Two groups of graves can be sorted out: an older one, with skeletal burials in supine position, within massive, rectangular or oval stone grave constructions, like the mound I 
Fig. 2. Prehistoric necropolis near Otilovići, Pljevlja, Montenegro. Documentation of Archaeological Collection, Faculty of Philosophy, Belgrade

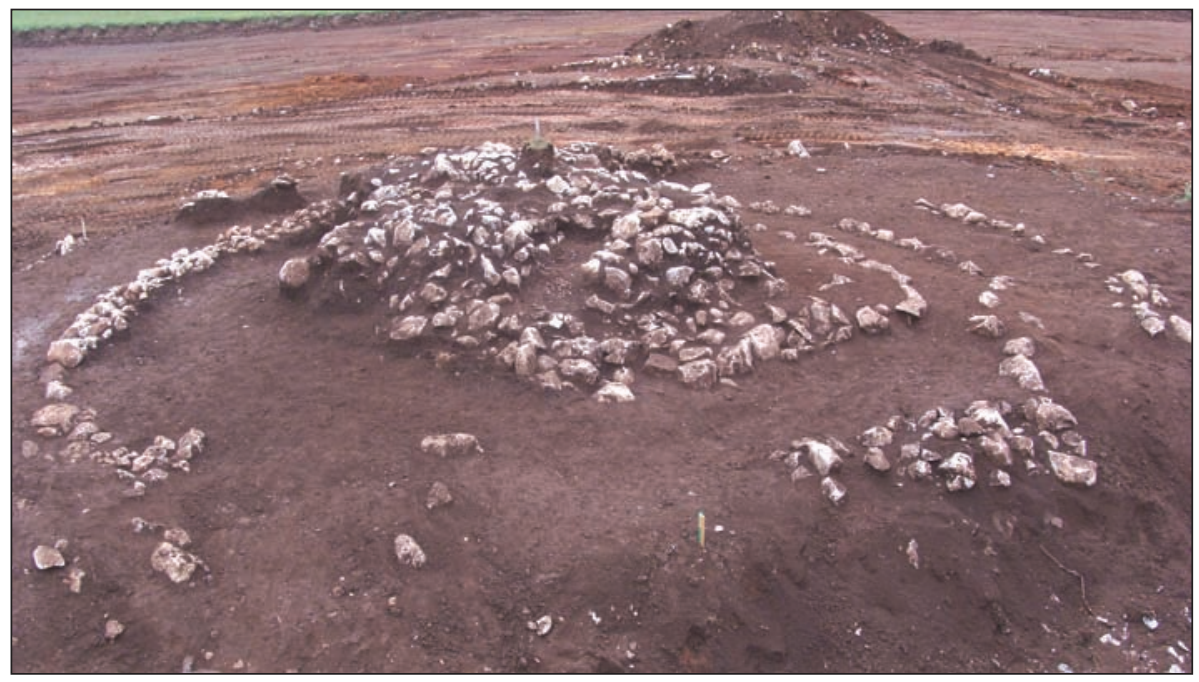

from the site Latinsko Groblje in Glogovik (fig. 3), with grave inventory resembling the one from the mentioned region of Pljevlja and a younger one, in which cremations predominate, with human remains scattered across foundations made of pebbles and broken stones. According to grave goods (more elaborated and refined bronze jewellery and ceramic vessels, sometimes imported or made under the influence of the material from north Greece or south Macedonia, or even from the Thracian world as it is the case with the Latinsko Groblje fibula), these younger bi-ritual burials are much stronger connected to Kosovo and southern parts of the Balkan peninsula, in contrast to the older ones, which are incorporated in the wider complex Glasinac-Mati (Jevtić, Ljuština 2008). The mentioned find of a small arc fibula (Jevtić 1990, p. 116, kat. 150) (length $2.4 \mathrm{~cm}$ ) of Thracian type from tumulus II at Latinsko Groblje (fig. 4) is from the same period or slightly later time in comparison to the black-brown varnished bowls of Greek production, which came mostly from cremated burials at several sites at the Pešter plateau. The fibula is dated at the end of the $4^{\text {th }}$ or $3^{\text {rd }}$ century BC (Vasic 2000, p. 15-19).

Thorough analysis of funerary practice of the older period revealed that a number of Basarabi elements were recognised in the material from the mound with incinerations in Melaje. At the base of the mound there was a large circular area, lined with a row of broken stones, with traces of intense fire. Pottery sherds were spread all over the earthen covering of the mound. Except the numerous fragments decorated with the false cord technique (fig. 5), there were some fragments of vessels made on potter's wheel, of Greek provenance, and also some hand-made pottery under the Greek influence. Only on the basis of the ceramic material, two burial horizons could have

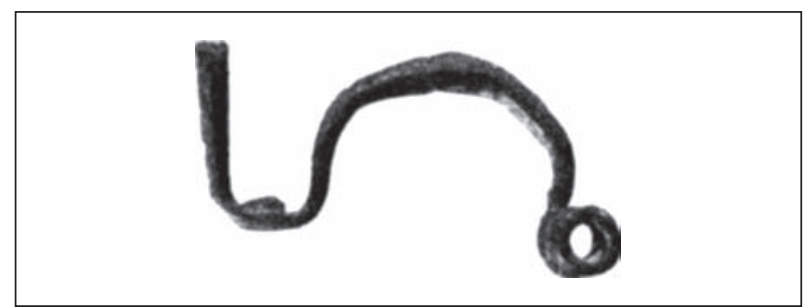

Fig. 4. Glogovik, Latinsko Groblje, Serbia: fibula from Mound II (Jevtić 1990)

been divided: a horizon with the false cord pottery of Basarabi style and a horizon with Greek imports. Fragments of vessels decorated in Basarabi style form a separate group of pottery. Parts of vessels decorated with rows of false cord came from the base of the mound. It is worth mention- 


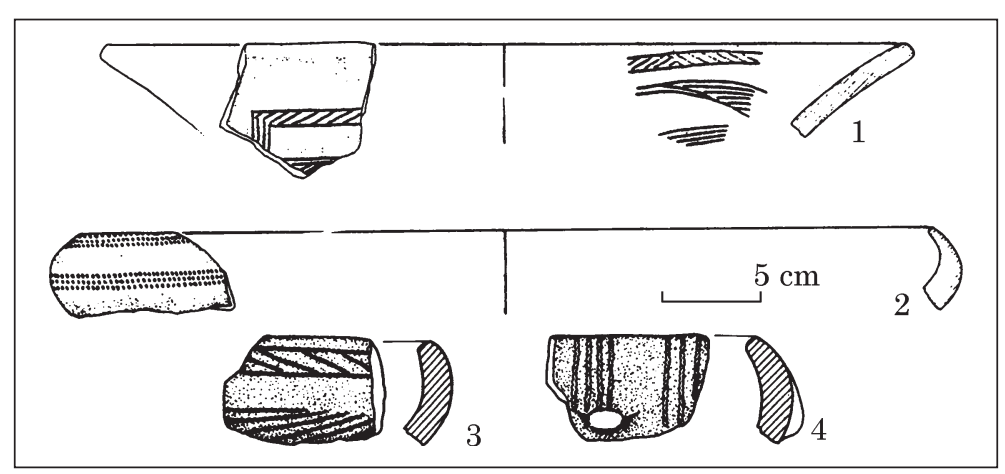

Fig. 5. Melaje, Livada kod džamije, Serbia: Basarabi pottery (Јевтић 1992)

ing that no trace of pottery with the «S» stamps decoration was found there, which is in contrast with the Basarabi pottery from the hillforts in the Novi Pazar area (Јевтић 1992, p. 8; Jevtić, Ljuština 2008, p. 43). There is a tempting idea, according to which a woman originating from the Triballi tribe (or generally from North-Thracian ethnical space) was cremated and buried among some local inhabitants of North-Dardanian origin. Ethnical attribution of the deceased is confirmed by both the sherds of the Basarabi bowls found at the mound base, and the small ceramic cogged tool, used for the pottery decoration. Such tools have been found mainly in the western part of the vast Basarabi complex, where the tremollo pottery was most common, and to which the early Triballi can be cautiously connected (Јевтић 1992, p. 15; Jevtić, Ljuština 2008, p. 45).

What strikes us as odd is that the latest date of the prehistoric finds from the region can be the $3^{\text {rd }}$ century BC. The following centuries BC left almost no trace in archaeological sense. If this observation about chronology of archaeological finds from the Hallstat period in the Pljevlja region and other parts of the territory of the Autariatae is connected with historical sources, it can lead to interesting and tempting hypotheses. M. Lazić and M. Cerović (Лазић, Церовић 2008) emphasized the often quoted information on movements of the Autariatae towards the east and their conflict with the Triballi. The migration of the Autariatae is not chronologically positioned with precision, although some historians, F. Papazoglu above all, consider it to have taken place after $335 \mathrm{BC}$. It was the most convenient moment to defeat the Triballi and expel them from their homeland, after the defeat by Alexander III of Macedon. However, the archaeological material from the Pljevlja region suggests different solutions. Absence of finds later than the $5^{\text {th }} \mathrm{c}$. BC in the area indicates an assumption that the Autariatae exactly in that period left it for good.

The absence of material from the Late Iron Age in this territory makes it difficult to deal with ethnic and cultural continuity and the question about who had lived there several centuries prior to the Roman conquest. Missing link could be sought in the inhumation burials under tumu- lus from Krajčinovići ( $2^{\text {nd }} / 1^{\text {st }}$ century BC) (Zotović 1985; 2007; Gabrovec, Čović 1987, p. 907; Jovanović 1987a, p. 828, 848; Jovanović 1987b, p. 813), although the finding conditions and the find itself are questionable.

The Krajčinovići- Slana voda necropolis was partly damaged by building a local road. The necropolis was in circular form, with the first level made of small stones on which 25 partially burnt male and female skeletons were placed, without recognised individual grave pits, with the legs to the centre and the heads to the edge of the necropolis. The tumulus was covered with stones, bigger in the central position and smaller to the edge of it. Inside the tumulus there were ceramic and bronze vessels, jewellery and weapons. Among the pottery, the material of the First Iron Age, Celtic and Hellenistic provenance or influence was recognised. The bronze vessels also reveal Hellenistic influence, as well as the jewellery made of silver. Some of the swords (the total of about 69 iron swords) were recognized as Celtic. Fibulae made of bronze of the Middle and Late La Tène scheme and glass beads should be mentioned at this point, too. The closest analogies for such funerary practices can be found in two necropolises in the territory of Bosnia and Herzegowina - Mahrevići near Čajniče and Vir near Posušje (Zotović 2007, p. 199). No matter how uncertain the mentioned finds are, the recognition of material from three ethnical and cultural zones - local Illyrian-Autariataean, Celtic and Hellenistic - in the $2^{\text {nd }}$ and $1^{\text {st }}$ centuries BC should be emphasized.

The first archaeological evidence of the inhabitants of this region after Autariatae dates from the $1^{\text {st }}$ century AD. During systematic researches in Komini near Pljevlja (ancient Municipium S.) carried out from 1964 to 1976, almost seven hundred graves were discovered, mostly cremated deceased buried from the $1^{\text {st }}$ to $4^{\text {th }}$ century (cf. Cermanović-Kuzmanović 1967; 1980a; 1980b; Цермановић-Кузмановић 1998; 2009). According to the research, there were two ancient necropolises. The older one, necropolis I, situated in the area of Bijelo brdo, and the later one, well-known in scientific literature as necropolis II, placed at the foot of the eponymous hill. The necropolis I, with about 400 graves of cremated burials of native non-Romanized population, dated to the $1^{\text {st }}$ and the beginning of the $2^{\text {nd }}$ century $\mathrm{AD}$, contained a few grave forms, which could be divided into two groups: graves with recipient and graves without receptacle for ashes of the dead. To the first group belong graves with oval/circular pit with remains from the pyre as well as rectangular pits with burned sides. The other group is represented by circular grave pits with ceramic urn (mostly handmade), which is often covered by a stone slab, or placed in the ring of stones i. e. surrounded by 
stones (fig. 6). To this group also belong graves with stone caskets for the ashes of the dead, concentrated in one section of the necropolis, while the other graves on the necropolis I are distributed without particular order (Цермановић-Кузмановић 1998; Цермановић-Кузмановић 2009).

Graves from the older necropolis in Komini contain simple grave goods, mostly composed of ceramic vessels (hand-made or wheel-thrown) and metal objects (bronze fibulae of the Aucissa type, rare bronze coins, rings and earrings), while the graves with long knives and spears with their tip dug into the earth are especially interesting (fig. 7). This custom is also familiar to the Iapodes. Some links and analogies with the Iapodean pottery are notable as well (Cermanović-Kuzmanović 1980a, p. 227-232; Цермановић-Кузмановић 1998; Цермановић-Кузмановић 2009; Ружић 2009). Aleksandrina Cermanović-Kuzmanović also denoted significant similarity with the material from the Cetina river (the Delmate region) (Цермановић-Кузмановић 1998; 2009).

As we have already seen, according to the several investigated tumuli, cremation was not known in the earlier sepulchral tradition, i. e. the native population used only inhumation under the mounds. With the beginning of new millennium, with the Roman occupation or even earlier, the burial rite changed (Јовановић 1984, p. 66). Since there is no evidence that the native population had cremation in their own sepulchral tradition and according to the grave forms and material from them, which cannot be ascribed to the Romanized population, it is believed that the new grave forms were probably adopted from the neighbouring regions, where cremation was dominant sepulchral form in the pre-Roman period. This custom is characteristic from the middle of the I millennium BC in the wider Illyrian region, from the Iapodes on the north-west to the southern Serbia and Kosovo on the south-east. It is suggested that this form could have been adopted from the north-west, from the territory of the Illyrian / Pannonian tribe Daesidiates, or from the east, or the Dardanians, Illyrian-Thracian tribe as suggested by A. Jovanović (cf. Cermanović-Kuzmanović 1982, p. 227-232; Јовановић 1984, p. 66). So far, several assumptions have been made in relation to this issue. Grave forms and grave goods (especially pottery finds) are indicative of relations with Iapodean, Dalmatian, Desidiatean and Dardanian cultural circle (Cermanović-Kuzmanović 1980a; Јовановић 1984; Цермановић-Кузмановић 1998; 2009). According to the opinion of A. Jovanović, grave pits without recipient for the ashes of the dead with the remains of the pyre or the pits with burned sides are older and belong to the native population. Having developed Evans' (Evans 1885, p. 38) idea, Jovanović stated about the Pirustae as autochthonous population, or the population which settled in today region of north Albania and north-eastern Montenegro (Јовановић 2011; 2012; the same problem was also dealt by J. Wilkes (Wilkes 1969) and A. Cermanović-

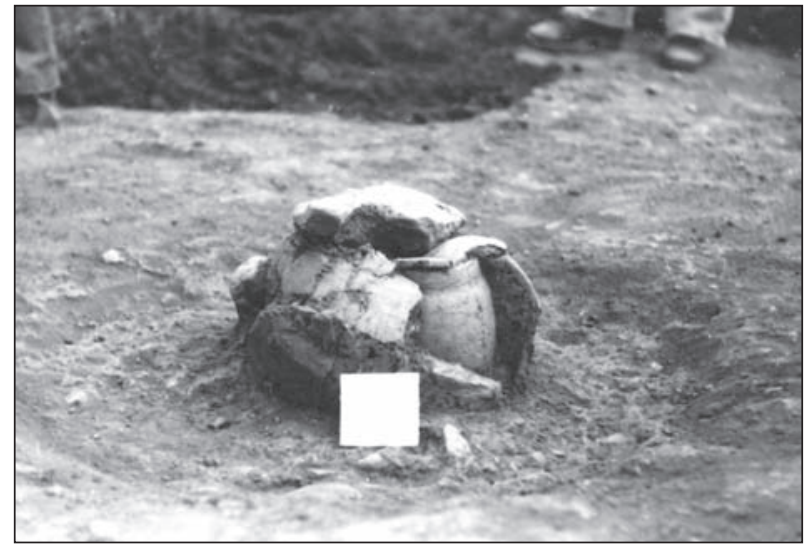

Fig. 6. Komini, Montenegro: ceramic urn covered and surrounded by stones from necropolis I. Documentation of Archaeological Collection, Faculty of Philosophy, Belgrade

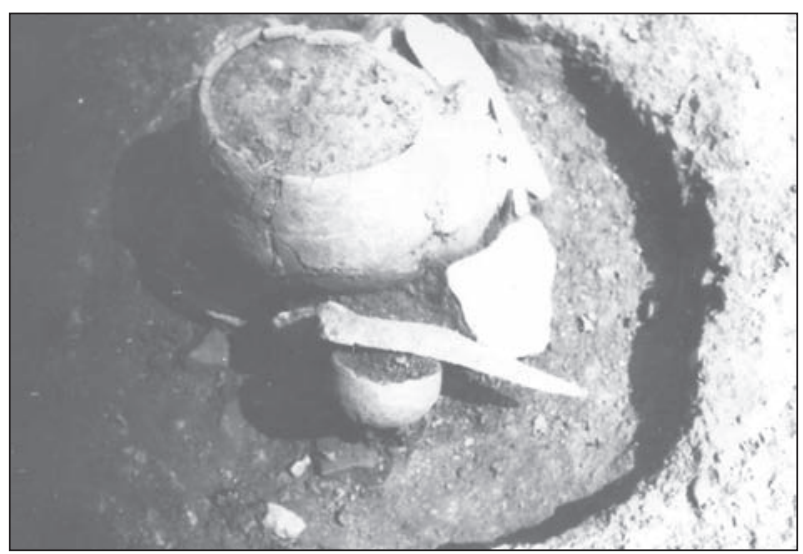

Fig. 7. Komini, Montenegro: grave with long knife, necropolis I. Documentation of Archaeological Collection, Faculty of Philosophy, Belgrade

Kuzmanović (Цермановић-Кузмановић 2009). Jovanović (Јовановић 1984, p. 64-68) supposes that this models came from the east or from the neighbouring territory of the Dardanians (basic forms of graves Mala Kopašnica Sase type) at the turn of the new era i. e. with the beginning of the Roman domination. The other grave form, or pits with urns and ash-chests (Aucissa type fibulae, long knives) occurred at beginning of the $2^{\text {nd }}$ century with population from the central Dalmatia. Moreover, it has been suggested that this depopulated area was resettled by the groups of refugees of the Scordisci and Dardaninas, during the $2^{\text {nd }}$ or the $1^{\text {st }}$ century BC (Лазић, Церовић 2013).

However, we are of the opinion that we could count on varied ethnic components in this territory in pre-Roman and early Ro-

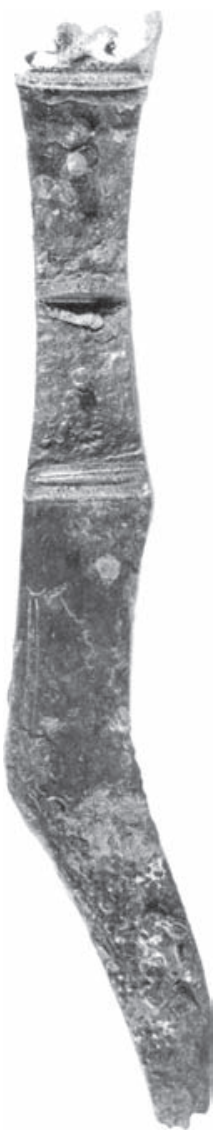




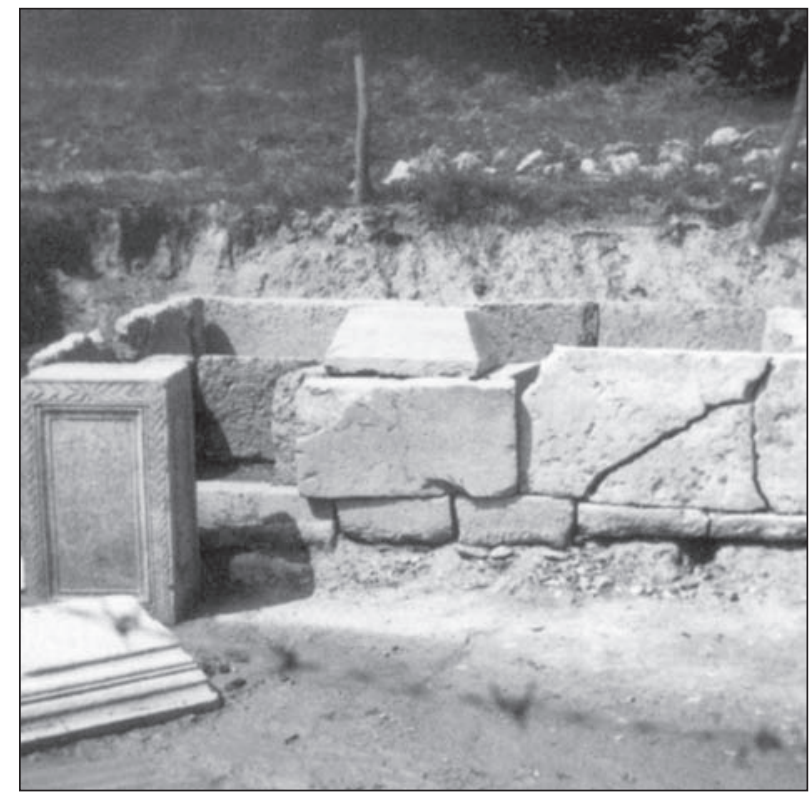

Fig. 8. Komini (Municipium S.) Montenegro: monumental tomb of the so-called Aquileian type, necropolis II. Documentation of Archaeological Collection, Faculty of Philosophy, Belgrade

man period, but also should be very careful with conclusions about indigenous population. All of the suggestions should be taken with caution, because the results of the excavations in Komini have not been completely published. They are the subject of the study which is in preparation.

On the other hand, epigraphic material from the younger necropolis in Komini, dated to the second half of the $2^{\text {nd }}$ century to the middle or the second half of the $4^{\text {th }}$ century $\mathrm{AD}$, are well known and published (Mirković 2013). A completely different picture of necropolis II indicates that the population inside this necropolis was mostly Romanised. Besides simple grave pits with container for ashes of the dead (urn, stone ossuary), there were several monumental tombs of the so-called Aquileian type, built by notable citizens of Municipium S (fig. 8). The wealthy part of the population was buried in grave pits with stone, often decorated ash chest (ossuary), which mostly contained rich and various materials imported from the farthest provinces of the Empire. Notable population of this Roman town also included veterans and soldiers from the legions and auxiliaries. On the necropolis II there are also excavated several graves of the cremated deceased with weapons, or the equipment for the members of the auxiliaries (Cvijetić 2017).

According to the onomastics, notable citizens of Municipium S. were mostly of Illyrian origin. However, we could consider presence of varied (Celtic, Thracian) ethnical entities, too (CermanovićKuzmanović 1967; 1969; 1980b; Јовановић 1984; Mirković 2013).

The presence of epigraphic confirmation of Thracian personal names during the $2^{\text {nd }}$ and $3^{\text {rd }}$ centuries $\mathrm{AD}$ refers to the mines in the area of

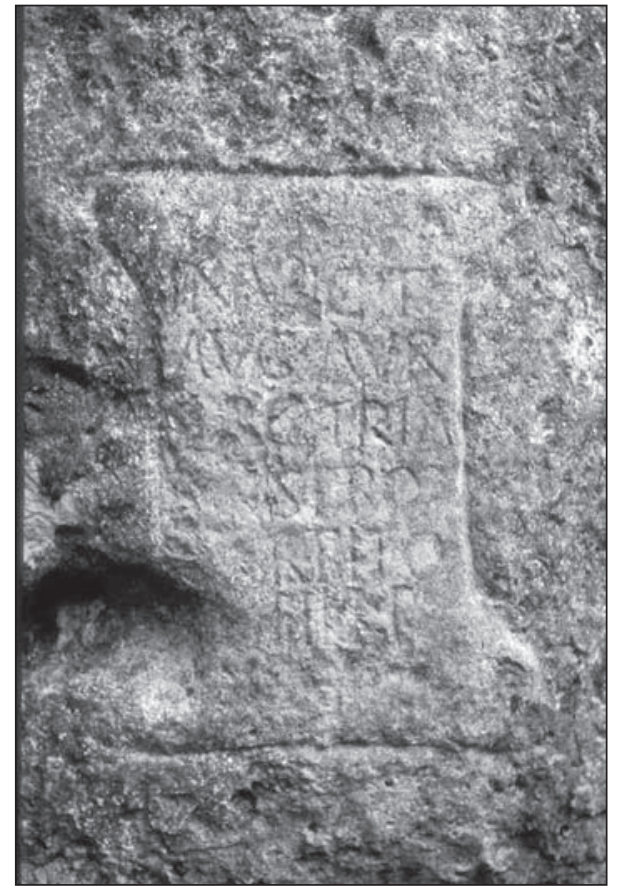

Fig. 9. Lever Tara, Montenegro: Inscription from Mithras temple. Documentation of Archaeological Collection, Faculty of Philosophy, Belgrade

present day Northern Montenegro and Southwest Serbia. Several names from Pljevlja and Prijepolje region, such as Teres, Bessus and Bessio could be of Thracian origin (Alföldy 1965, p. 15, 98; Mirković 2013 , p. $45,48,101)$. However, it is interesting to note that the name Bessus is present in Dalmatia, Gallia, Noricum, Dacia and Moesia, etc. but not on the territory of Thrace (Mirković 2013, p. 45). The name Teres is recorded as part of the nomen formula of vir perfectissimus (governor) of Roman province of Thrace from 305 to 311 AD (Sharankov 2016, p. 105, 106). But, on the other hand R. Katičić suggested even in the late 60 s of last century that Teres was from Terenti, and Bessus were Illyrian names (Katičić 1963, p. 264, 277; also see Loma 2003-2014, p. 40). M. Mirković suggests that name Bessus could be of Thracian but also of Celtic origin, according to the significant number of recorded epigraphic testimonies from Gallic territories (Mirković 2013, p. 46; Lörincz 2005, p. 289).

It should be emphasized that these few names should not be necessarily connected with the native population. It should be kept in mind that certain individuals or families could have been moved from the other parts of the Balkans to this territory during the Roman period (Mirković 2013, p. 44-50). The names-ethnics are common in the epigraphic material from this region. From that point of view especially are interesting the names Bessus and Bessio which could be ethnics, or the names derivate from name of the Thracian tribe Bessi. If we read carefully historical sources, we will find a significant note from Appian (Ill. 1, 16). As he testifies, the Romans took a war against the Bessi, somewhere in the territory of Illyricum during $\mathrm{O}$. Au- 
gustus (35-33 BC) (Mirković 2013, p. 45). Part of this Thracian tribe was moved to Dalmatia, by the order of M. Antonius. They could have been partly moved into this metalliferous part of the province for exploitation of silver (Alfoldy 1965, p. 67-69; Јовановић 2012, p. 156). Also, according to the opinion of G. Alföldy, two more names from the territory of ancient Municipium S. could be of the Thracian origin. The name Plares is noticed in region of Pljevlja and Prijepolje, and the other one is known from Komini and Lever Tara. According to the opinion M. Mirković, Plares (also Plarens) belongs to the Illyrian names (Mirkovic 2013, p. 100). The name of Aurelius Argyrianus is mentioned with the function of imperial procurator on the inscription from the Mithras temple in Lever Tara. According to G. Alföldy, name Argyrianus / Argurianus could be Thracian or Celtic origin (Alföldy 1964, p. 124). On the other side S. Loma suggested Illyrian origin (Loma 2003-2004, p. 48) and M. Mirković reminds us that the reading of the name on a monument from Lever Tara is uncertain (Mirković 2013, p. 114, 99, note 114). The official, by all accounts, carried out the administration of the mines in this area during the seventies of the $3^{\text {rd }}$ century (fig. 9) (Лома 1999, p. 193-202; Лома 2003, p. 12, 21; on the organization of mining in the province of Dalmatia: Dušanić 1980; on the administrative status of Eastern Dalmatia and eastern Dalmatian mines: Лома 1999; Лома 2003). A couple of inscriptions from Čadinje near Prijepolje and Bijelo Polje indicate exploitation of mineral resources in northern Montenegro and south-western Serbia (CIL III, 12715; Mirković 1975, p. 105, 106; ILJug 137, no. 1817; ILJug 1685; Лома 2003, p. 12, ref. 5; Cvijetić 2014).

Finally, a very attractive assumption is made by A. Jovanović. According to him, ancient Thermidava, in Ptolemy listed in the towns of the province of Dalmatia (Ptol. II, 16 (17)), should probably be sought somewhere in the territory of northern Montenegro or northwest Albania. In his opinion, the etymology of the place name - Thermidava - a compound of the prefix therme - spa and the sufix dava - Thracian name for the settlement, suggests a settlement developed near hot springs, and which has a Thracian component (Јовановић 2012, р. 155, 156). The connection between hot springs and mines is clear, but unfortunately from the archaeological point of view this territory is still terra incognita.

In the end, we can only conclude that one of the most challenging but also the most difficult questions for the archaeologists and one of the most important tasks for the future exploration is at least partial enlightening the structure of the population the Romans found in this area at the turn of the new era.

Aknowledgements. The paper represents the result of work within the projects Romanisation, Urbanisation and Transformation of Urban Centres of Civil, Military and Residential Character in Roman Provinces on the Territory of Serbia
(177007), and Society, Culture and Communications in the Balkans in proto- and early history (177012), funded by the Ministry of Education, Science and Technological Development of the Republic of Serbia.

\section{BIBLIOGRAPHY}

Alföldy, G. 1964. Die Namengebung der Urbevölkerung in der Römischen Provinz Dalmatia. Beiträge zur Namenscforschung, 15, p. 98-102.

Alföldy, G. 1965. Bevölkerung und Gesellschaft der Römischen Provinz Dalmatien. Budapest: Akadémiai Kiadó.

Benac, A. 1987. O etničkim zajednicama starijeg željeznog doba u Jugoslaviji. In: Benac, A. (ed.). Praistorija jugoslavenskih zemalja V. Željezno doba. Sarajevo: Centar za balkanološka ispitivanja Akademije nauka i umjetnosti Bosne i Hercegovine, p. 737-802.

Cermanović-Kuzmanović, A. 1967. Rezultati arheoloških istraživanja na području Municipijuma S... kod Pljevalja - selo Komini. Materijali, IV, p. 77-84.

Cermanović-Kuzmanović, A. 1969. Neue Funde aus dem Municipium S. Hommages á Marcel Renard III, Collection Latomus, 103, p. 116-123.

Cermanović-Kuzmanović, A. 1980a. Vorrömische Elemente in der Kultur des Municipium S. im Dorfe Komini. Živa antika, 30, p. 227-232.

Cermanović-Kuzmanović, A. 1980b. Arheološko istraživanje antičkih nekropola u selu Komini kod Pljevalja. Starinar, n. s., 31, p. 43-52.

CIL. 1873. Corpus Inscriptionum Latinarum III, Inscriptiones Asiae, provinciarum Europae Graecarum, Illyrici Latinae. Th. Mommsen.

Cvijetić, J. 2014. Contribution to the knowledge of autochthonous cults in southeast Dalmatia and the problem of locating ancient Thermidava. New Antique Doclea, V, p. 59-68.

Cvijetić, J. 2017. Stamped Shield-boss from Municipium S. (Montenegro). In: Vujović, M. (ed.). Ante portam auream. Studia in honorem professoris Aleksandar Jovanović. Belgrade: Faculty of Philosophy Belgrade, p. 211-223.

Cović, B. 1987. Glasinačka kultura. In: Benac, A. (ed.). Praistorija jugoslavenskih zemalja $V$. Željezno doba. Sarajevo: Centar za balkanološka ispitivanja Akademije nauka i umjetnosti Bosne i Hercegovine, p. 575-643.

Evans, A. 1885. Antiquarian Researches in Illyricum. Archaeologia, XLIX, p. 1-167.

Fol, V., Popov, D., Yordanov, K. 2014. The Thracian Kings. Sofia: Tangra TanNakRa.

Gabrovec, S., Cović, B. 1987. Zaključna razmatranja. In: Benac, A. (ed.). Praistorija jugoslavenskih zemalja V. Željezno doba. Sarajevo: Centar za balkanološka ispitivanja Akademije nauka i umjetnosti Bosne i Hercegovine, p. 901-928.

ILJug-Šašel, A., Šašel, J. 1986. Inscriptiones Latinae quae in Iugoslavia inter annos MCMII-MCMXL repertae et editae sunt. Ljubljana.

Jevtić, M. 1990. Early Iron Age in Western Serbia and Metohija. In: Jeftović, J. (ed.). Masters of Silver The Iron Age in Serbia. Belgrade; Novi Sad; Priština: National Museum, Museum of Vojvodina, Museum of Kosovo, p. 109-117.

Jevtić, M., Ljuština, M. 2008. Some Thracian Elements from the Iron Age Tumular Graves in Novi Pazar Area (South-western Serbia). In: Sîrbu, V., Stîngă, I. (eds). The Iron Gates Region during the Second Iron Age: Settlements, Necropolises, Treasures. DrobetaTurnu Severin, Craiova: Editura Universitaria Craiova, p. 38-56. 
Jovanović, B. 1987a. Istočna grupa. In: Benac, A. (ed.). Praistorija jugoslavenskih zemalja V. Željezno doba. Sarajevo: Centar za balkanološka ispitivanja Akademije nauka i umjetnosti Bosne i Hercegovine, p. 815-854.

Jovanović, B. 1987b. Uvod. In: Benac, A. (ed.). Praistorija jugoslavenskih zemalja V. Željezno doba. Sarajevo: Centar za balkanološka ispitivanja Akademije nauka i umjetnosti Bosne i Hercegovine, p. 805-814.

Loma, S. 1999. Zum Mithrasdenkmal im Taratal (CIL III 13849). Starinar, n. s., XLIX, p. 193-202.

Lörincz, B. 2005. Onomasticon provinciarum Europae latinarum I-IV, Budapest: Archaeolingua Alapitvany.

Mirković, M. 1975. Iz istorije Polimlja. Godišnjak Centra zabalkanološka ispitivanja, XIV, 12, p. 95-107.

Mirković, M. 2013. Municipium S. Rimski grad u Kominima kod Pljevalja. Beograd: Filozofski fakultet u Beogradu.

Katičić, R. 1963. Das mitteldalmatische Namengebiet. Živa antika, 12, p. 255-292.

Sladić, M. 2012. Praistorijski tumuli u Otilovićima kod Pljevalja. Davnine. Arheologija u Crnoj Gori, 1, p. 59-101.

Knapp, A. B. 2014. Mediterranean Archaeology and Etnicity. In: McInerney, J. (ed.). A Companion to the Ethnicity in the Ancient Mediterranean. Chichester: Wiley Blackwell, p. 34-49.

Sharankov, N. 2016. Notes of Governors of the Roman Thrace. Bulletin of the National Archaeological Institute, XLIV: Proceedings of the First International Roman and Late Antique Thrace Conference "Cities, Territories and Identities» (Plovdiv, $3^{\text {rd }}-7^{\text {th }}$ October 2016), p. 97-109.

Vasić, R. 2000. Thracian Fibulae in the West: Invasion or Cultural Exchange? Archaeologia Bulgarica, 4, 1, p. 13-20.

Wilkes, J. J. 1969. Dalmatia, History of the provinces of the Roman Empire. London: Harvard University Press.

Zotović, M. 1985. Arheološki i etnički problemi bronzanog $i$ guozdenog doba zapadne Srbije. Doctoral thesis, University of Belgrade, Faculty of Philosophy, Deparment of Archaeology.

Zotović, R. 2007. Social and Cultural Aspects of the Burial "Krajčinovići-Slana voda» (south-west of Serbia, middle of II c. BC). Funerary Practices in Europe, before and after Roman Conquest ( $3^{\text {rd }}$ century $B C-3^{\text {rd }}$ century AD). Proceedings of the $8^{\text {th }}$ International Colloquium of Funerary Archaeology, p. 199-205.

Цермановић-Кузмановић, А. 1998. КоминиMunicipium S..., некрополе. Београд: Филозофокки факултет.

Цермановић-Кузмановић, А. 2009. Пљеваљско подручје у римско и рановизантијско доба. У: Терзић, С. (ред.). Историја Пљеваља. Пљевља: Општина Пљевља, с. 51-67.

Душанић, С. 1980. Организација римског рударства у Норику, Панонији, Далмацији и Горњој Мезији. Историјски гласник, 1-2, с. 7-55.

Јевтић, М. 1992. Налази Басараби културе у новопазарском крају. Новопазарски зборник, 16, с. 7-16.

Јевтић, М. 1996. О истраживању млађих праисторијских култура у новопазарском крају. Новопазарски зборник, 20, с. 7-13.

Јовановић, А. 1984. Рилске некрополе на територији Југославије. Београд: Центар за археолошка истраживања.

Јовановић, А. 2011. Пирусти и Албурнус: огледи о укљеви и традицији. Зборник Матище српске за класичне студије, 13, с. 7-12.

Јовановић, А. 2012. Белешке о култу воде у римским провинщијама на тлу Србије. Зборник Матице српске за класичне студије, 14, с. 151-162.
Лазић, М., Церовић, М. 2013. Становништво пљеваљског краја пре и после романизације - од VI столећа пре н. е. до IV столећа н. е. (Пљевља, 07.-08. јуни 2008. године). Гласник Завичајног музеја (Пљевљља), 8-9, с. 9-26.

Летица, 3. 1982. Пештер у бронзано и гвоздено доба. Старинар, н. с., 32, с. 9-17.

Лома, С. 2003. Проблеми идентификације, територије и становништва Муниципија С. Гласник Завичајног музеја (Пльевља), 3, с. 9-23.

Лома, С. 2003-2004. Домаће становништво Муниципија С. у светлу нових епиграфских сведочанстава. Cтаринар, н. с., LIII-LIV, с. 35-63.

Ружић, М. 2009. Силван и Херкул у загробним веровањима становника Муниципијума С. Архаика, 2, c. $103-118$.

Срејовић, Д. 2009. Пљеваљско подручје у праисторији. У: Терзић, С. (ред.). Историја Плеваља. Пљевља: Општина Пљевља, с. 35-47.

\section{REFERENCES}

Alföldy, G. 1964. Die Namengebung der Urbevölkerung in der Römischen Provinz Dalmatia. Beiträge zur Namenscforschung, 15, p. 98-102.

Alföldy, G. 1965. Bevölkerung und Gesellschaft der Römischen Provinz Dalmatien. Budapest: Akadémiai Kiadó.

Benac, A. 1987. O etničkim zajednicama starijeg željeznog doba u Jugoslaviji. In: Benac, A. (ed.). Praistorija jugoslavenskih zemalja V. Željezno doba. Sarajevo: Centar za balkanološka ispitivanja Akademije nauka i umjetnosti Bosne i Hercegovine, p. 737-802.

Cermanović-Kuzmanović, A. 1967. Rezultati arheoloških istraživanja na području Municipijuma S... kod Pljevalja selo Komini. Materijali, IV, p. 77-84.

Cermanović-Kuzmanović, A. 1969. Neue Funde aus dem Municipium S. Hommages á Marcel Renard III, Collection Latomus, 103, p. 116-123.

Cermanović-Kuzmanović, A. 1980a. Vorrömische Elemente in der Kultur des Municipium S. im Dorfe Komini. Živa antika, 30, p. 227-232.

Cermanović-Kuzmanović, A. 1980b. Arheološko istraživanje antičkih nekropola u selu Komini kod Pljevalja. Starinar, n. s., 31, p. 43-52.

CIL. 1873. Corpus Inscriptionum Latinarum III, Inscriptiones Asiae, provinciarum Europae Graecarum, Illyrici Latinae. Th. Mommsen.

Cvijetić, J. 2014. Contribution to the knowledge of autochthonous cults in southeast Dalmatia and the problem of locating ancient Thermidava. New Antique Doclea, V, p. 59-68.

Cvijetić, J. 2017. Stamped Shield-boss from Municipium S. (Montenegro). In: Vujović, M. (ed.). Ante portam auream. Studia in honorem professoris Aleksandar Jovanović. Belgrade: Faculty of Philosophy Belgrade, p. 211-223.

Čović, B. 1987. Glasinačka kultura. In: Benac, A. (ed.). Praistorija jugoslavenskih zemalja V. Željezno doba. Sarajevo: Centar za balkanološka ispitivanja Akademije nauka i umjetnosti Bosne i Hercegovine, p. 575-643.

Evans, A. 1885. Antiquarian Researches in Illyricum. Archaeologia, XLIX, p. 1-167.

Fol, V., Popov, D., Yordanov, K. 2014. The Thracian Kings. Sofia: Tangra TanNakRa.

Gabrovec, S. Čović, B. 1987. Zaključna razmatranja. In: Benac, A. (ed.). Praistorija jugoslavenskih zemalja V. Željezno doba. Sarajevo: Centar za balkanološka ispitivanja Akademije nauka i umjetnosti Bosne i Hercegovine, p. 901-928.

ILJug-Šašel, A., Šašel, J. 1986. Inscriptiones Latinae quae in Iugoslavia inter annos MCMII-MCMXL repertae et editae sunt. Ljubljana.

Jevtić, M. 1990. Early Iron Age in Western Serbia and Metohija. In: Jeftović, J. (ed.). Masters of Silver The Iron Age in Serbia. Belgrade; Novi Sad; Priština: National Museum, Museum of Vojvodina, Museum of Kosovo, p. 109-117.

Jevtić, M., Ljuština, M. 2008. Some Thracian Elements from the Iron Age Tumular Graves in Novi Pazar Area (South- 
western Serbia). In: Sîrbu, V., Stîngă, I. (eds). The Iron Gates Region during the Second Iron Age: Settlements, Necropolises, Treasures. Drobeta-Turnu Severin, Craiova: Editura Universitaria Craiova, p. 38-56.

Jovanović, B. 1987a. Istočna grupa. In: Benac, A. (ed.). Praistorija jugoslavenskih zemalja $V$. Željezno doba. Sarajevo: Centar za balkanološka ispitivanja Akademije nauka i umjetnosti Bosne i Hercegovine, p. 815-854.

Jovanović, B. 1987b. Uvod. In: Benac, A. (ed.). Praistorija jugoslavenskih zemalja V. Željezno doba. Sarajevo: Centar za balkanološka ispitivanja Akademije nauka i umjetnosti Bosne i Hercegovine, p. 805-814.

Loma, S. 1999. Zum Mithrasdenkmal im Taratal (CIL III 13849). Starinar, n. s., XLIX, p. 193-202.

Lörincz, B. 2005. Onomasticon provinciarum Europae latinarum I-IV, Budapest: Archaeolingua Alapitvany.

Mirković, M. 1975. Iz istorije Polimlja. Godišnjak Centra zabalkanološka ispitivanja, XIV, 12, p. 95-107.

Mirković, M. 2013. Municipium S. Rimski grad u Kominima kod Pljevalja. Beograd: Filozofski fakultet u Beogradu.

Katičić, R. 1963. Das mitteldalmatische Namengebiet. Živa antika, 12, p. 255-292.

Sladić, M. 2012. Praistorijski tumuli u Otilovićima kod Pljevalja. Davnine. Arheologija u Crnoj Gori, 1, p. 59-101.

Knapp, A. B. 2014. Mediterranean Archaeology and Etnicity. In: McInerney, J. (ed.). A Companion to the Ethnicity in the Ancient Mediterranean. Chichester: Wiley Blackwell, p. 34-49.

Sharankov, N. 2016. Notes of Governors of the Roman Thrace. Bulletin of the National Archaeological Institute, XLIV: Proceedings of the First International Roman and Late Antique Thrace Conference «Cities, Territories and Identities» (Plovdiv, $3^{\text {rd }}-7^{\text {th }}$ October 2016), p. 97-109.

Vasić, R. 2000. Thracian Fibulae in the West: Invasion or Cultural Exchange? Archaeologia Bulgarica, 4, 1, p. 13-20.

Wilkes, J. J. 1969. Dalmatia, History of the provinces of the Roman Empire. London: Harvard University Press.

Zotović, M. 1985. Arheološki i etnički problemi bronzanog $i$ guozdenog doba zapadne Srbije. Doctoral thesis, University of Belgrade, Faculty of Philosophy, Deparment of Archaeology. Zotović, R. 2007. Social and Cultural Aspects of the Burial «Krajčinovići-Slana voda» (south-west of Serbia, middle of II c. BC). Funerary Practices in Europe, before and after Roman Conquest (3rd century $B C-3^{\text {rd }}$ century $A D$ ). Proceedings of the $8^{\text {th }}$ International Colloquium of Funerary Archaeology, p. 199-205.

Cermanović-Kuzmanović, A. 1998. Komini-Municipium S..., nekropole. Beograd: Filozofski fakultet u Beogradu.

Cermanović-Kuzmanović, A. 2009. Pljevaljsko područje u rimsko i ranovizantijsko doba. In: Terzić, S. (ed.). Istorija Pljevalja. Pljevlja: Opština Pljevlja, s. 51-67.

Dušanić, S. 1980. Organizacija rimskog rudarstva u Noriku, Panoniji, Dalmaciji i Gornjoj Meziji. Istorijski glasnik, 1-2, s. 7-55. Jevtić, M. 1992. Nalazi Basarabi kulture u novopazarskom kraju. Novopazarski zbornik, 16, s. 7-16.

Jevtić, M. 1996. O istraživanju mlađih praistorijskih kultura u novopazarskom kraju. Novopazarski zbornik, 20, s. 7-13.

Jovanović, A. 1984. Rimske nekropole na teritoriji Jugoslavije. Beograd: Centar za arheološka istraživanja.

Jovanović, A. 2011. Pirusti i Alburnus: ogledi o ukljevi tradiciji. Zbornik Matice srpske za klasične studije, 13, s. 7-12.

Jovanović, A. 2012. Beleške o kultu vode u rimskim provincijama na tlu Srbije. Zbornik Matice srpske za klasične studije, 14, s. 151-162.

Lazić, M., Cerović, M. 2013. Stanovništvo pljevaljskog kraja pre i posle romanizacije - od VI stoleća pre n. e. do IV stoleća n. e. (Pljevlja, 07.-08. juni 2008. godine). Glasnik Zavičajnog muzeja (Pljevlja), 8-9, s. 9-26.

Letica, Z. 1982. Pešter u bronzano i gvozdeno doba. Starinar, n. s., 32, s. 9-17.

Loma, S. 2003. Problemi identifikacije, teritorije istanovništva Municipija S. Glasnik Zavičajnog muzeja (Pljevlja), 3, c. 9-23.

Loma, S. 2003-2004. Domaće stanovništvo Домаће становништво Municipija S. u svetlu novih epigrafskih svedočanstava.y светлу нових епиграфских сведочанстава. Starinar, n. s., LIII-LIV, s. 35-63.

Ružić, M. 2009. Silvan i Herkul u zagrobnim verovanjima stanovnika Municipijuma S. Arhaika, 2, s. 103-118.

Srejović, D. 2009. Pljevaljsko područje u praistoriji. In: Terzić, S. (ed.). Istorija Pljevalja. Pljevlja: Opština Pljevlja, s. 35-47.

\section{М. Люштіна, Е. Цвієтіч}

\section{ПРО ЕТНГЧНІ КОМПОНЕНТИ У ФОРМУВАННІ АРХЕОЛОГІЧНОӦ КАРТИНИ ПІВДЕННО-ЗАХІДНОЇ СЕРБIÏ ТА ПІВНІЧНОЇ ЧОРНОГОРІї ЗА ПЕРЕДРИМСЬКОЇ ТА РАННОЇ РИМСЬКОЇ ДОБИ}

Головною метою дослідження $є$ визначення етнічних компонентів та їх значення у створенні археологічної картини Південно-Західної Сербії та Північної Чорногорії в передримському та ранньому римському періоді. Обраний регіон був невід'ємною частиною іллірійського світу, але наприкінці пізнього передримського періоду знаходився на порозі фракійського світу. Що ж до наступного періоду римського панування, то однією з найважливіших завдань майбутнього дослідження $є$ принаймні часткове висвітлення структури населення, з яким римляни зітнулися на цій території на рубежі нової ери.

В археологічній картині досліджуваної території переважає значна кількість курганних некрополів. Найбільша кількість курганних поховань належить до фінального горизонту раннього залізного віку/гальштатського періоду. Не викликає сумніву, що в пізньому гальштатті цей район було включено до культурного комплексу Гласинац-Маті. Відсутність матеріалу пізнього залізного віку на цій території ускладнюе дослідження етнічної та культурної спадкоємності і питання про те, хто жив там кілька століть до римського завоювання. Відсутні ланки можна було б шукати в інгумащійних похованнях в кургані з Крайчиновічі, де слід підкреслити наявність у II-I ст. до н. е. матеріалу з трьох етнічних і культурних зон - місцевих іллірійсько-авторіанських, кельтських і елліністичних.

Оскільки немае жодних свідоцтв того, що серед поховальних традищій корінного населення була кремація, а поховальні споруди і матеріали з них не можна приписати романизованому населенню, слід припустити, що нові поховальні споруди, ймовірно, були запозичені з сусідніх регіонів, де кремація була домінуючим поховальним обрядом у передримський період.

Ми вважаємо, що можна враховувати різноманітні етнічні компоненти на цій території в передримський і ранньоримський періоди, але також треба бути дуже обережними з висновками про корінне населення, поховане на некрополі I. Усі висновки мають буди вельми обережними, оскільки результати розкопок в Коміні ще не повністю опубліковані. Вони є предметом дослідження, яке готується.

Ключові слова: залізний вік, римська доба, Чорногорія, Сербія, некрополі, Муніщипіум С, іллірійщі, фрракійці.

Одержано 21.12.2018

ЛЮШТІНА Марія, доктор археології, асистент профресора, Університет Білграду, вул. Чіка Любіна 18-20, Білград, 11000, Сербія, mljustin@f.bg.ac.rs.

LJUŠTINA Marija, PhD, Assistant Professor, University of Belgrade, Čika Ljubina 18-20, Belgrade, 11000, Serbia,mljustin@f.bg.ac.rs.

ЦВІСТІЧ Елена, доктор археології, асистент професора, Університет Білграду, вул. Чіка Любіна 18-20, Білград, 11000, Сербія, jcvijeti@f.bg.ac.rs.

CVIJETIĆ Jelena, PhD, Assistant Professor, University of Belgrade, Čika Ljubina 18-20, Belgrade, 11000, Serbia, jcvijeti@f.bg.ac.rs. 